Proceedings of XIX International Scientific Conference "New Technologies and Achievements in Metallurgy, Material Engineering, Production Engineering and Physics", Częstochowa, Poland, June 7-8, 2018

\title{
Analysis of Phase Transformation in Nickel-Base Alloy after Ageing
}

\author{
A. Merda ${ }^{a, *}$, A. ZIELIŃSki ${ }^{b}$ AND G. GolańSKI ${ }^{a}$ \\ ${ }^{a}$ Częstochowa University of Technology, Faculty of Production Engineering and Materials Technology, \\ Institute of Materials Engineering, Częstochowa, Poland \\ ${ }^{b}$ Stanisław Staszic Institute for Ferrous Metallurgy, Gliwice, Poland
}

\begin{abstract}
The aim of the performed tests was to analyse the precipitation processes in the $23 \mathrm{Cr}-45 \mathrm{Ni}-6 \mathrm{~W}-\mathrm{Nb}-\mathrm{Ti}-\mathrm{B}$ (HR6W) alloy based on nickel. The examined material was subjected to the process of long-term isothermal annealing at $700{ }^{\circ} \mathrm{C}$, for various time periods of up to $10000 \mathrm{~h}$. The scope of the tests included: structural tests using scanning electron microscopy, the analysis of the precipitation processes with the use of X-ray phase analysis and electron diffraction with transmission electron microscopy. The tests showed that only MX-type precipitates occurred in the analysed alloy in the as-received condition, whereas the long-term annealing contributed to the precipitation of secondary phases of $\mathrm{M}_{23} \mathrm{C}_{6}$ carbides and the Laves phase.
\end{abstract}

DOI: 10.12693/APhysPolA.135.98

PACS/topics: HR6W alloy, microstructure, precipitate

\section{Introduction}

The HR6W nickel-base alloy was developed in the 1990s in Japan as a material for components of steam superheaters operating at up to $800^{\circ} \mathrm{C}$. This alloy is characterised by creep strength, which is intermediate between that of high-chromium martensitic steels and of nickel superalloys. Creep strength of the HR6W alloy is the result of strong solid solution strengthening by tungsten and nitrogen atoms and precipitation hardening by particles of $\mathrm{M}_{23} \mathrm{C}_{6}$ and $\mathrm{MC}$ carbides and Laves phase. Due to high chromium content, higher than that in austenitic steels, this alloy is characterised by resistance to oxidation in steam atmosphere and to "hot corrosion" [1,2].

The suitability of creep-resistant steels and alloys for use in components and installations of power units is determined by labour- and time-consuming tests of microstructure stability and mechanical properties under ageing conditions at a temperature similar to that of the expected service. For creep-resistant steels and alloys with austenitic matrix the main processes affecting the microstructure degradation and reduction in functional properties, including corrosion resistance, are precipitation and changes in the morphology of secondary phases [3-8]. Knowledge of the sequence of secondary phase precipitations and linking them with changes in mechanical properties will allow building a database and characteristics of specific alloy in terms of its applicability for long-term service under creep conditions $[2,3]$. The aim of the performed tests was to analyse the precipitation processes in $\mathrm{HR} 6 \mathrm{~W}$ alloy subjected to isothermal ageing at $700^{\circ} \mathrm{C}$ for $10000 \mathrm{~h}$.

\footnotetext{
* corresponding author
}

\section{Material and research methodology}

The testing covered creep-resistant nickel-base alloy HR6W with chemical composition is set out in Table I. The test material was subjected to isothermal annealing at $700^{\circ} \mathrm{C}$ for up to $10000 \mathrm{~h}$.

TABLE I

Chemical composition of HR6W steel [wt\%].

\begin{tabular}{c|c|c|c|c}
\hline \hline $\mathrm{C}$ & $\mathrm{Si}$ & $\mathrm{Mn}$ & $\mathrm{P}$ & $\mathrm{S}$ \\
\hline 0.10 & 1.00 & 1.50 & 0.01 & 0.01 \\
\hline \hline $\mathrm{Cr}$ & $\mathrm{W}$ & $\mathrm{Ti}$ & $\mathrm{Nb}$ & $\mathrm{Ni}$ \\
\hline 21.50 & 7.00 & 0.20 & 0.35 & 45.00
\end{tabular}

The range of the performed tests included:

- The analysis of microstructure using the optical microscope Axiovert 25 and the scanning electron microscope JEOL JSM-6610LV, the structural tests were performed on metallographic microsections etched with ferric chloride;

- The X-ray structural examinations performed using the X-ray diffractometer Seifert XRD - 3003TT;

- Identification of precipitates by selective electron diffraction using the transmission electron microscope Titan 80-300.

\section{Research results and their analysis}

\subsection{Microstructure of the test alloy in the as-received condition}

Similarly to creep-resistant steels with austenitic structure, the HR6W alloy in the as-received condition is delivered in solution condition. The solution heat treatment is to obtain a homogeneous structure with no precipitates. The chemical composition of the test alloy 
includes strongly carbide-forming alloying elements, i.e. niobium and titanium. Therefore, numerous primary precipitates in nickel austenite matrix are observed in its microstructure in the as-received condition. In the structure of HR6W alloy, there are also annealing twins, which is characteristic of alloys with A1 structure (Fig. 1). Two morphologies of primary precipitates were revealed in the test alloy: particles with a globular-like shape and particles with a rectangular shape. The globular precipitates were rich in niobium, while the rectangular ones were rich in titanium. The example of primary precipitate in HR6W alloy in the as-received condition is shown in Fig. 2. Also, the X-ray structural examinations confirmed the existence of this type of precipitates in the test alloy (Fig. 3a). The performed identifications revealed that the first of them was $\mathrm{NbC}$ precipitates, while the latter was TiN precipitates. A part of TiN particles precipitated by nucleating heterogeneously on $\mathrm{Al}_{2} \mathrm{O}_{3}$ oxides. Similarly, the complexes of $\mathrm{TiN}-\mathrm{Al}_{2} \mathrm{O}_{3}$ precipitates were observed in [9]. The primary precipitates in the structure of the test alloy existed mainly inside the austenite grains, and some of these particles were observed near and at the grain boundaries (Fig. 1).
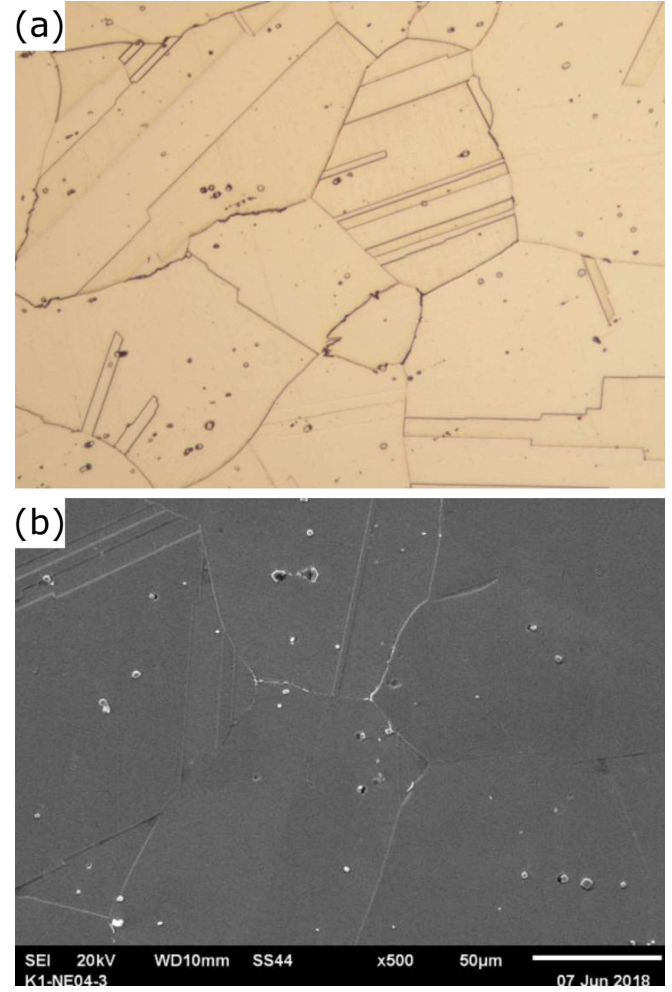

Fig. 1. Microstructure of HR6W alloy in the asreceived condition: (a) optical microscopy (OM), (b) scanning electron microscopy (SEM).

According to [10], in HR6W alloy in the as-received condition (i.e. after solution heat treatment) there were also primary $\mathrm{M}_{23} \mathrm{C}_{6}$ carbides in addition to primary $\mathrm{MX}$ precipitates. Precipitates of this type were not observed in the test alloy.

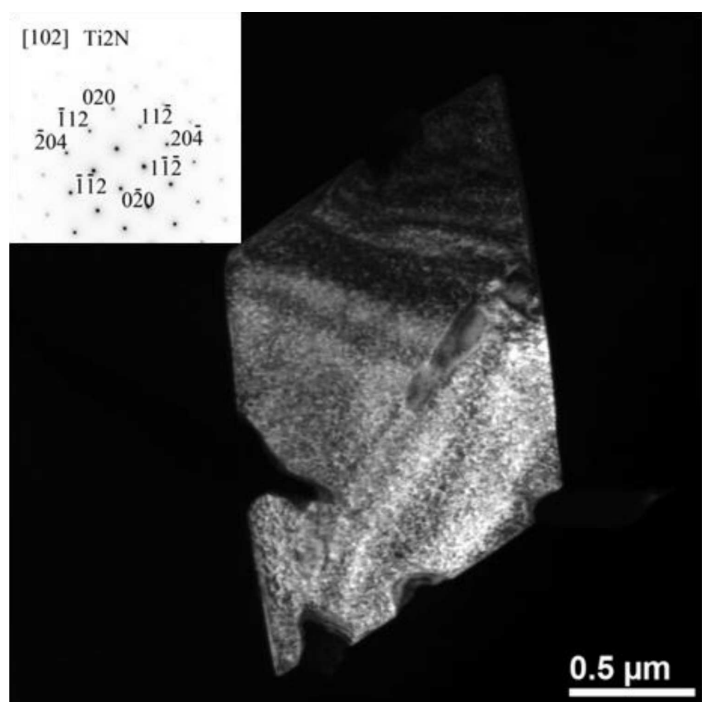

Fig. 2. Microstructure of primary TiN precipitate in HR6W alloy in the as-received condition, dark field; on the left corner - diffraction pattern of TiN precipitate.
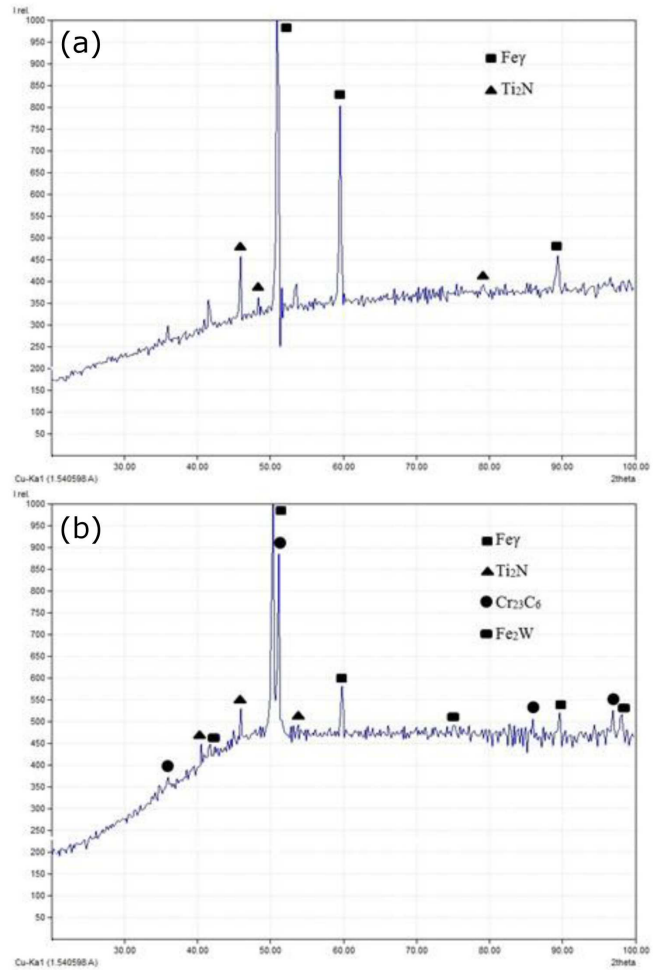

Fig. 3. Diffraction pattern of precipitates in the test alloy: (a) in the as-received condition, (b) following ageing at $700{ }^{\circ} \mathrm{C}$ after $10000 \mathrm{~h}$.

\subsection{Microstructure of the test alloy after ageing}

The ageing of the test alloy mainly contributed to the intensive precipitation processes. The first, privileged place of precipitation of secondary phases in austenitic matrix alloy is the grain boundaries as areas with increased energy and the way of easy diffusion. As the energy of the incoherent twin boundary represents ap- 
proximately 0.7 and the energy of the coherent boundary represents $0.2-0.3$ of the energy of the large-angle boundary [11], at the next stage the precipitation took place at the twin boundaries and inside the grains. In creepresistant alloys, precipitates at the grain boundaries hamper sliding at the boundaries, thus increasing the creep resistance $[4,5,12]$. However, this effect disappears in case of formation of the so-called continuous network of precipitates by particles, which results in the increase in brittleness and contributes to a change in cracking mechanism from ductile to brittle, frequently intercrystalline [3]. The effect of negative impact of particles precipitated at the grain boundaries in austenitic matrix alloy is visible on the example of HR3C steel [3, 13].

In the microstructure of the test alloy, the presence of $\mathrm{M}_{23} \mathrm{C}_{6}$ carbides and Laves-phase precipitates were observed at the grain and twin boundaries (Fig. 4).
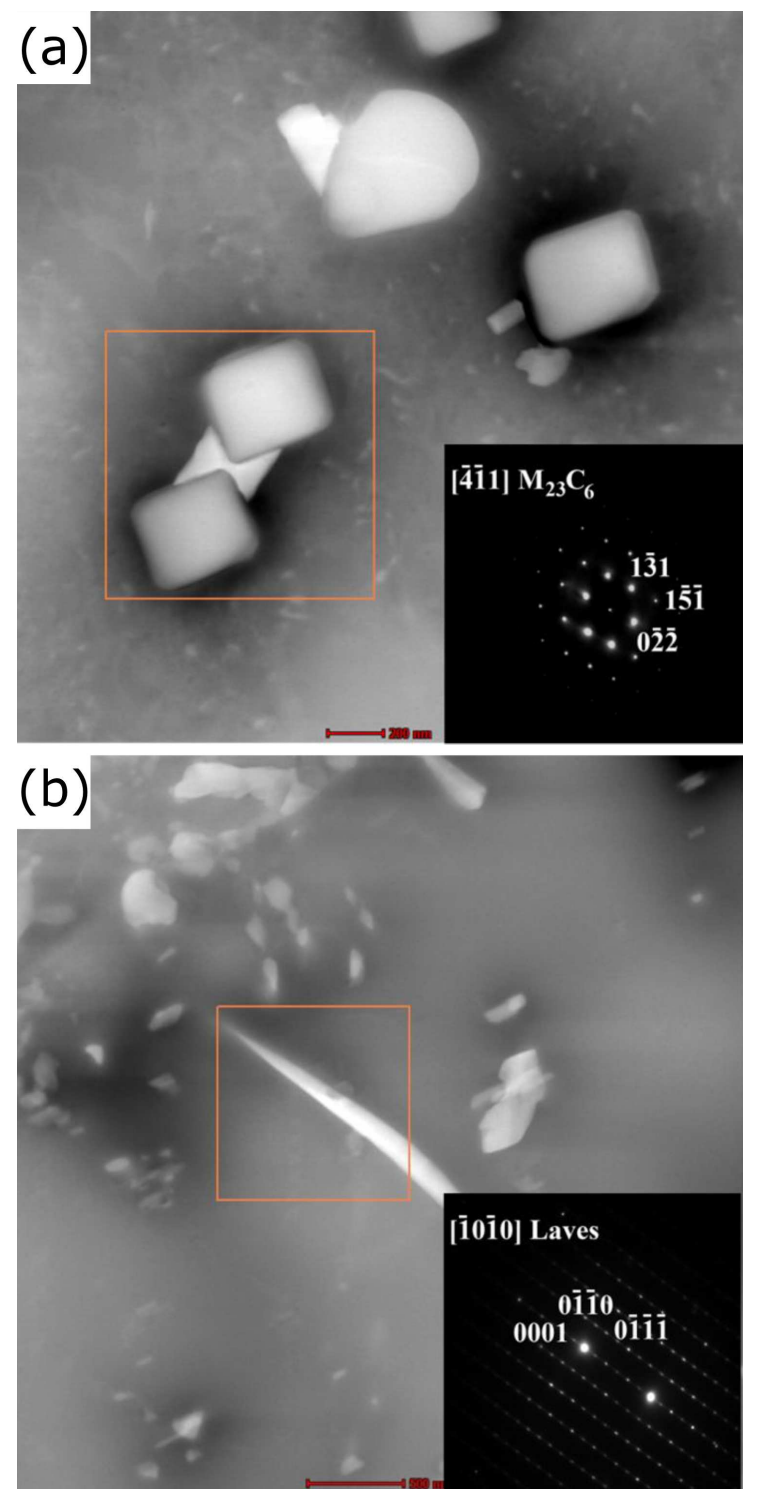

Fig. 4. Microstructure of precipitates in the test alloy after ageing at $700{ }^{\circ} \mathrm{C}$ for $10000 \mathrm{~h}$ : (a) $\mathrm{M}_{23} \mathrm{C}_{6}$ carbides, (b) Laves phase.
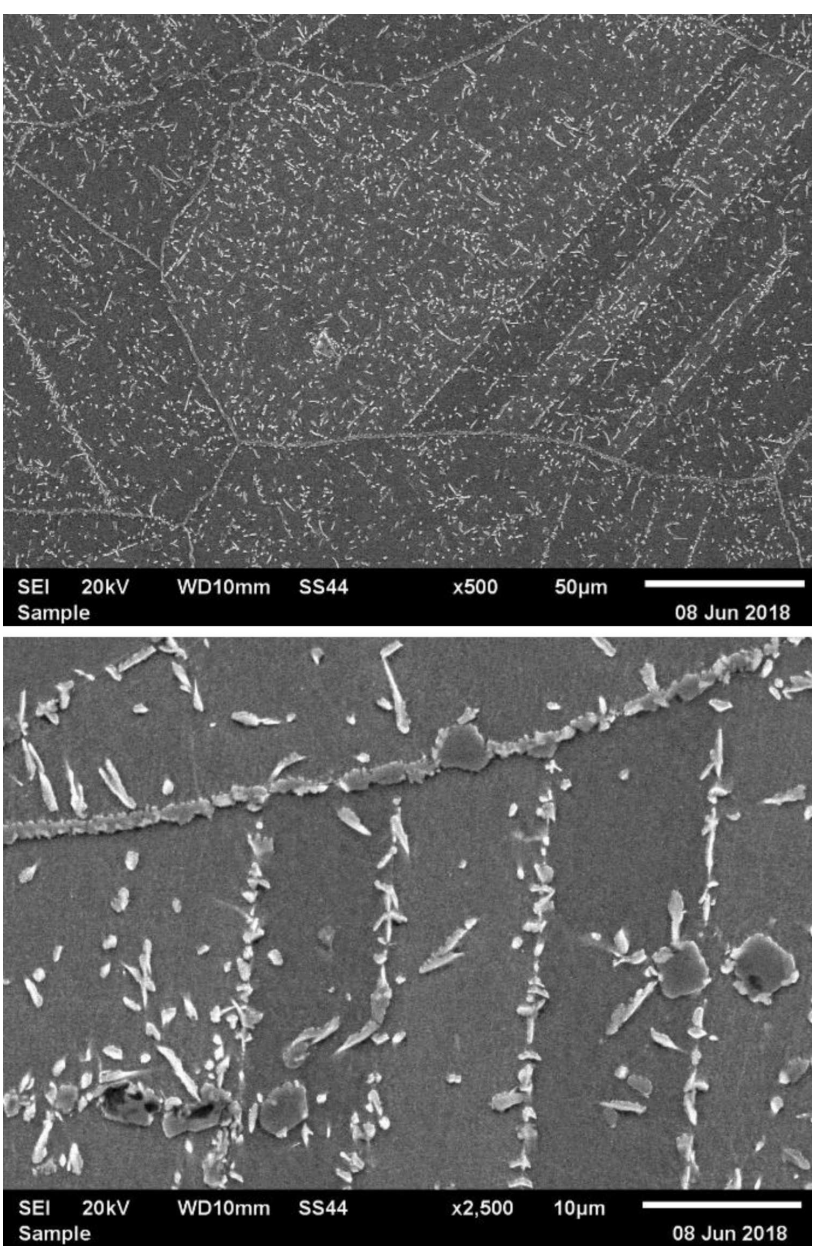

Fig. 5. Microstructure of HR6W alloy after ageing at $700{ }^{\circ} \mathrm{C}$ for $10000 \mathrm{~h}$

The numerous precipitates observed at the boundaries form the so-called continuous network of precipitates (Fig. 5). In steels with austenitic matrix, $\mathrm{M}_{23} \mathrm{C}_{6}$ carbides are the first secondary precipitates occurring in the structure of these materials during ageing/service [5, 12]. $\mathrm{M}_{23} \mathrm{C}_{6}$ carbides (Fig. 4a) are characterised by low stability at elevated temperature and a tendency to form the so-called continuous network of precipitates at the grain boundaries, which results in the decrease in mechanical properties, and also in the reduction in corrosion resistance $[3-5,13]$. According to $[5,11,12]$, not only the amount of $\mathrm{M}_{23} \mathrm{C}_{6}$ particles precipitated at the grain boundaries, but also their shape determine their impact on the properties. The $\mathrm{M}_{23} \mathrm{C}_{6}$ precipitates with a lamellar-like shape ensure higher creep strength than those with a wedge-like shape, whereas the Laves-phase precipitates (Fig. 4b) in an alloy of this type are considered favourable provided that the phase is relatively fine. The growth of this phase leads to the reduction in creep strength and crack resistance $[2,4,10]$. Inside the grains, in addition to primary MX precipitates, numerous relatively fine secondary precipitates of $\mathrm{M}_{23} \mathrm{C}_{6}$ carbides are observed. 

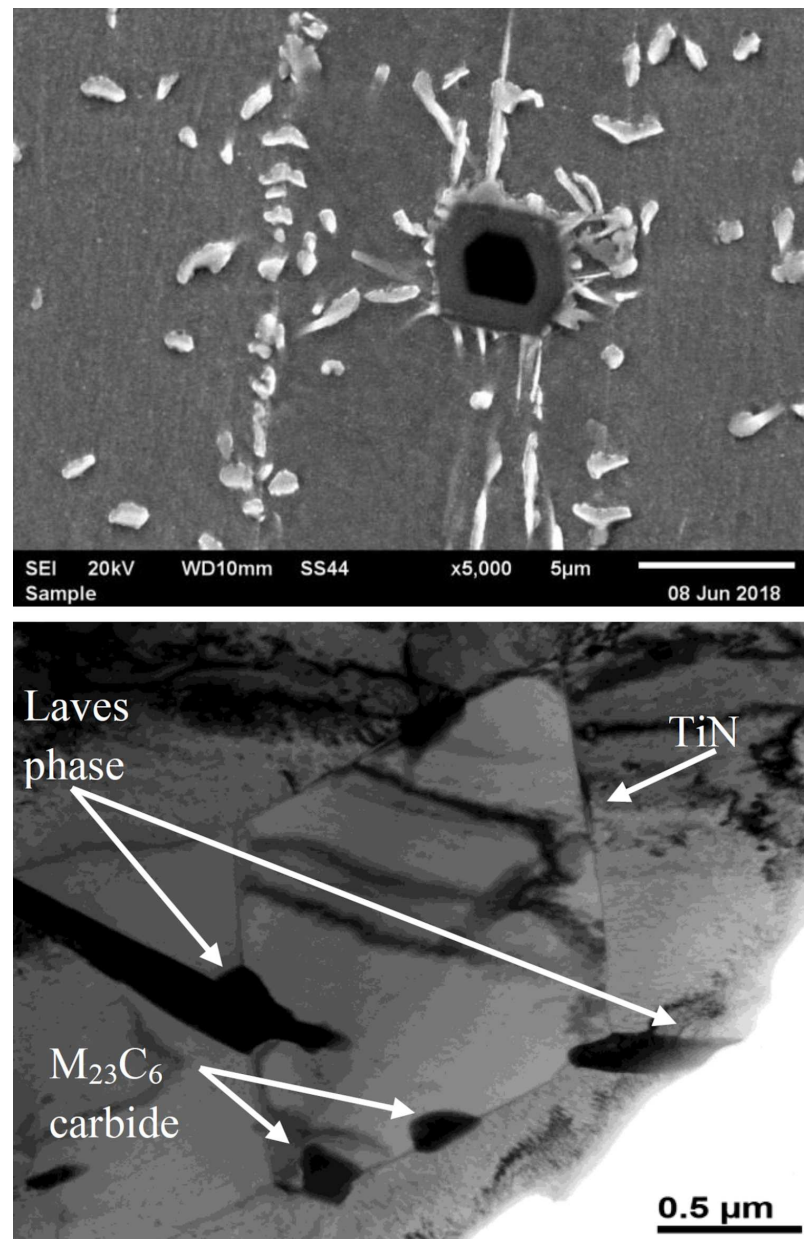

Fig. 6. Microstructure of composite complex in the test alloy after ageing at $700{ }^{\circ} \mathrm{C}$ for $10000 \mathrm{~h}$.

Apart from these precipitates, the existence of composite complexes of TiN - the Laves phase - $\mathrm{M}_{23} \mathrm{C}_{6}$ carbide precipitates were revealed inside the grains in the test alloy (Fig. 6), whereas the $\mathrm{M}_{23} \mathrm{C}_{6}$ particles and the Laves phase nucleate heterogeneously on the TiN precipitate. Similar complexes of precipitates in HR6W alloy were observed after $5000 \mathrm{~h}$ ageing at $750^{\circ} \mathrm{C}$ [14]. Heterogeneous nucleation on TiN precipitates may result from favourable crystalline relationships among the networks of precipitates and fluctuations in chemical composition as well as from higher nucleation activation energy on the intercrystalline boundaries compared to that inside the grain. The composite complexes of precipitates in creep-resistant alloys were observed by, but not limited to $[9,14-16]$. According to [17], the formation of composite complexes of AlN-NbX ("caps") in steel results from the fact that the system aims at reduction in its internal energy and from the fact of easier nucleation on the intercrystalline border than in the matrix. The authors also mention the favourable crystalline relationship among these precipitates. The formation of composite complexes of $\mathrm{AlN}-\mathrm{M}_{23} \mathrm{C}_{6}$ and $\mathrm{AlN}-\mathrm{NbC}$ in the $9-12 \% \mathrm{Cr}$ steel is accompanied by the appearance of zones depleted in precipitates in the vicinity of these complexes and by the increase of distance among these precipitates. In the near-boundary precipitate-depleted zones, the accelerated process of matrix recrystallisation and reduction in strength properties takes place. Consequently, this leads to uneven course of the creep process within the grain volume and accelerated failure. In $9-12 \% \mathrm{Cr}$ steels, the NbX-VX complexes, specified as the "V-wings", which are an obstacle to the movement of dislocations resulting in the increase in creep resistance, are also observed [16]. After the specific time of ageing, no presence of the $\sigma$ phase precipitates was disclosed in the test alloy, which confirms the favourable effect of tungsten on inhibiting and delaying the precipitation of this harmful intermetallic phase [2]. The presence of precipitates $\left(\mathrm{M}_{23} \mathrm{C}_{6}\right.$ carbides, Laves phase, TiN nitride) in the microstructure of HR6W alloy after ageing was confirmed by the X-ray structural diffraction analysis (Fig. 3b).

\section{Summary}

This paper presents the results of precipitate identification by selective electron diffraction and X-ray structural examinations in HR6W alloy in the as-received condition and after $10000 \mathrm{~h}$ ageing at $700{ }^{\circ} \mathrm{C}$. The performed identifications revealed that only primary MX precipitates rich in niobium and/or titanium - $\mathrm{NbC}$, TiN were observed in $\mathrm{HR} 6 \mathrm{~W}$ alloy in the as-received condition. A part of TiN precipitates occurs as a result of heterogeneous nucleation on $\mathrm{Al}_{2} \mathrm{O}_{3}$ oxides. The ageing process results in the occurrence of numerous secondary phase precipitates with diverse morphologies in the structure. At the grain boundaries, the presence of $\mathrm{M}_{23} \mathrm{C}_{6}$ carbides and the Laves phase precipitations were revealed. Inside the grains, the precipitations of $\mathrm{M}_{23} \mathrm{C}_{6}$ carbides, the Laves phase and composite complexes of TiN- $\mathrm{M}_{23} \mathrm{C}_{6^{-}}$ Laves phase were observed in addition to primary $\mathrm{MX}$ precipitates. No $\sigma$-phase precipitates were disclosed in the test alloy after $10000 \mathrm{~h}$ ageing at $700^{\circ} \mathrm{C}$.

\section{References}

[1] A. Di Gianfrancesco, in: Materials for UltraSupercritical and Advanced Ultra-Supercritical Power Plants, Ed. A. Di Gianfrancesco, 2017, p. 423.

[2] H. Semba, H. Okada, M. Igarashi, in: Advances in Materials Technology for Fossil Power Plants, Eds. R. Viswanthan, D. Gandy, K. Coleman, Florida 2008, p. 168.

[3] A. Zieliński, M. Sroka, A. Hernas, M. Kremzer, Archiv. Metall. Mater. 2, 61 (2016).

[4] J. Yan, Y. Gu, J. Lu, Mater. Sci. Technol. 4, 31 (2015).

[5] T. Sourmail, Mater. Sci. Technol. 1, 17 (2001).

[6] M. Sroka, A. Zieliński, A. Hernas, Z. Kania, R. Rozmus, T. Tański, A. Śliwa, Metalurgija 333, 56 (2017).

[7] A. Zieliński, J. Dobrzański, H. Purzyńska, G. Golański, Mater. Test. 859, 57 (2015). 
[8] A. Zieliński, J. Dobrzański, H. Purzyńska, R. Sikora, M. Dziuba-Kałuża, Z. Kania, Archiv. Metall. Mater. 2057, 62 (2017).

[9] S. Roy, S. Patra, S. Neogy, A. Laik, S.K. Choudhary, D. Chakrabarti, Metall. Mater. Trans. A 43, 1845 (2012).

[10] T. Tokairin, K.V. Dahl, H. Kjartansson Danielsen, F.B. Grumsen, T. Sato, J. Hald, Mater. Sci. Eng. A 565, 285 (2013)

[11] K. Kaneko, T. Fukunaga, K. Yamada, N. Nakada, M. Kikuchi, Z. Saghi, J.S. Barnard, P.A. Midgley, Scr. Mater. 65, 509 (2011).

[12] K.H. Lo, C.H. Shek, J.K.L. Lai, Mater. Sci. Eng. R 65, 39 (2009).
[13] G. Golański, C. Kolan, A. Zieliński, K. Klimaszewska, A. Merda, M. Sroka, J. Kłosowicz, Archiv. Mater. Sci. Mech. Propert. 2, 81 (2016).

[14] P. Jamrozik, M. Sozańska, Solid State Phenom. 246, 33 (2016).

[15] H. Naoi, M. Ohgami, X. Liu, T. Fujita, Metall. Mater. Trans. A 28, 1195 (1997).

[16] K. Hamada, K. Tokun, Y. Tomita, H. Mabuchi, K. Okamoto, ISIJ Int. 1, 35 (1995).

[17] M.J. Leap, E.L. Brown, Scr. Mater. 47, 793 (2002). 